University of Nebraska - Lincoln

DigitalCommons@University of Nebraska - Lincoln

1999

\title{
Atrazine Degradation in a Small Stream in lowa
}

Dana W. Kolpin

US. Geological Survey

Stephen J. Kalkhoff

US. Geological Survey

Follow this and additional works at: https://digitalcommons.unl.edu/usgsstaffpub

Part of the Earth Sciences Commons

Kolpin, Dana W. and Kalkhoff, Stephen J., "Atrazine Degradation in a Small Stream in lowa" (1999). USGS Staff -- Published Research. 74.

https://digitalcommons.unl.edu/usgsstaffpub/74

This Article is brought to you for free and open access by the US Geological Survey at DigitalCommons@University of Nebraska - Lincoln. It has been accepted for inclusion in USGS Staff -- Published Research by an authorized administrator of DigitalCommons@University of Nebraska - Lincoln. 


\title{
Atrazine Degradation in a Small Stream in Iowa
}

\author{
Dana W. Kolpln and Stephen J. Kalkhoff*
}

U.S. Geological Survey, Box 1230, Iowa City, Iowa 52244

- A study was conducted during 1990 through an $11.2-\mathrm{km}$ reach of Roberts Creek in northeastern Iowa to determine the fate of atrazine in a surface water environment. Water samples were collected at $\sim 1$-month intervals from April through November during stable low to medium flow conditions and analyzed for atrazine and two of its initial biotic degradation products, desethylatrazine and deisopropylatrazine. Samples were collected on the basis of a Lagrangian model of streamflow in order to sample the same parcel of water as it moved downstream. Atrazine concentrations substantially decreased (roughly 25-60\%) between water entering and exiting the study reach during four of the seven sampling periods. During these same four sampling periods, the concentrations of the two biotic atrazine degradation products were constant or decreasing downstream, suggesting an abiotic degradation process.

\section{Introduction}

The production of abundant food crops in Iowa is accomplished by fertilization with chemical nutrients and control of competing vegetation with herbicides. Atrazine [2-chloro-4-(ethylamino)-6-(isopropylamino)-s-triazine] has a history of continual, widespread use as a corn (Zea mays [L.]) herbicide in Iowa. A survey of pesticides used in Iowa crop production in 1990 showed that $61 \%$ (roughly 3 million ha) of the corn was treated with atrazine, corresponding to an application of $\sim 3.4$ million $\mathrm{kg}$ of active ingredient to Iowa soils (1). Results of recent studies show that atrazine is present year round in streams in Iowa and other midwestern states $(2-4)$. These and other studies have documented the widespread occurrence of atrazine in surface waters in the midwestern United States, but much is yet to be learned about the fate of atrazine once it enters surface water.

There is a long history of research examining the fate of atrazine in soils and aquifers (5-9), but substantially less research on the fate of atrazine in surface waters. Previous investigations suggest that atrazine may not be conservative in small streams as it moves along surface water pathways. During a study of a watershed in southwestern Ontario, Roberts et al. (10) found that atrazine residues were consistently larger at upstream sites than at the mouth of the stream. Results of seepage studies of a small stream draining agricultural land in northeast Iowa during low-flow conditions $(4,11,12)$ showed a decrease in both atrazine concentration and load downstream in sections of Roberts Creek. In laboratory studies, Goldberg et al. (13) found that atrazine degraded by indirect photolysis in water samples collected from the Cedar River and its tributaries and Jones et al. (14) demonstrated atrazine degraded in estuarine water/sediment microcosm systems.

The purpose of this study was to examine the fate of atrazine transported in a small stream draining agricultural land during medium to low-flow conditions at various times throughout an entire growing season (April-November). This paper presents the results of that study and discusses possible physical, chemical, and biological processes that could affect atrazine in a stream environment.

\section{Methods}

An 11.2-km reach of Roberts Creek, extending from sampling sites RC18 to RC22 (Figure 1) was chosen for study. This section of Roberts Creek is ideal for investigating the fate of chemical constituents in surface water due to the simplified mass balance for this area. During most times of the year, there are no surface water or groundwater contributions to streamflow and thus no dilution or addition of atrazine. Because of the absence of chemical input, measured differences in chemical concentration should be due only to biotic or abiotic processes acting within this section of the stream.

The study reach is in a karstic region of northeastern Iowa, called the Big Spring Basin. Bedrock in the region consists of jointed and fractured carbonates with evidence of dissolution activity. The study reach has a contributing drainage area of $\sim 16 \mathrm{~km}^{2}$, more than $50 \%$ of which is planted in corn. The remaining land use in decreasing percentage consists of cover crops (mainly pasture, alfalfa, and oats), forests, and cultural features (urben development, roads, and quarries). Vegetative cover within a $30-\mathrm{m}$-wide riparian zone along the study reach is described by Kolpin and Kalkhoff (15)

The study reach consists of a pool-and-riffle sequence common to many small midwestern streams. The stream bed slopes $\sim 0.19 \mathrm{~m} / \mathrm{km}$, and the channel width varies from about 1.5 to $9 \mathrm{~m}$ through the study reach. Roberts Creek flows over substantial sections of exposed bedrock and has a layer of silt present in the ponded areas. Emergent vegetation along the stream bed and banks affected streamflow as the 1990 growing season progressed.

Previous studies $(11,16)$ have shown that the entire study reach loses water from the stream into the underlying bedrock aquifer. Local residents have noted the presence of sinkholes and fractures in the stream bed from which the loss of streamflow could, at times, be observed. There are seven intermittent streams that drain into the study reach. These intermittent streams flow only during periods of high runoff, which generally occur during snowmelt and intense rainfall. No perennial streams discharge into the study reach. There are no known field tile lines draining into the study reach due to adequate natural drainage in the area. Streamflow has been recorded continuously since March 1986 at a site (RC2) 3.9 $\mathrm{km}$ downstream of the study reach.

Sampling Scheme. The sampling scheme used in this study was based on a piston flow or Lagrangian model of streamflow in which water entering the study reach would flow as a unit through the entire reach. In this model, water in all parts of the stream travels at the same rate. However, streamflow is much more complex than this. The water in the center of the stream and the center of the water column travels faster than water on the edges due to decreased friction from the stream bed and banks. This results in instream mixing of water that may alter solute concentrations. However, if the amount of atrazine entering the study reach is constant, instream mixing remains constant, and the Lagrangian model becomes a good approximation of flow in a small stream.

Atrazine concentrations do not appear to change rapidly in the study reach during stable flow conditions. Kalkhoff (11) found that during midsummer the atrazine concentration in Roberts Creek was nearly constant during a 24-h period. This short-term consistency of analyte concentrations at a site increases the acceptable margin of error 


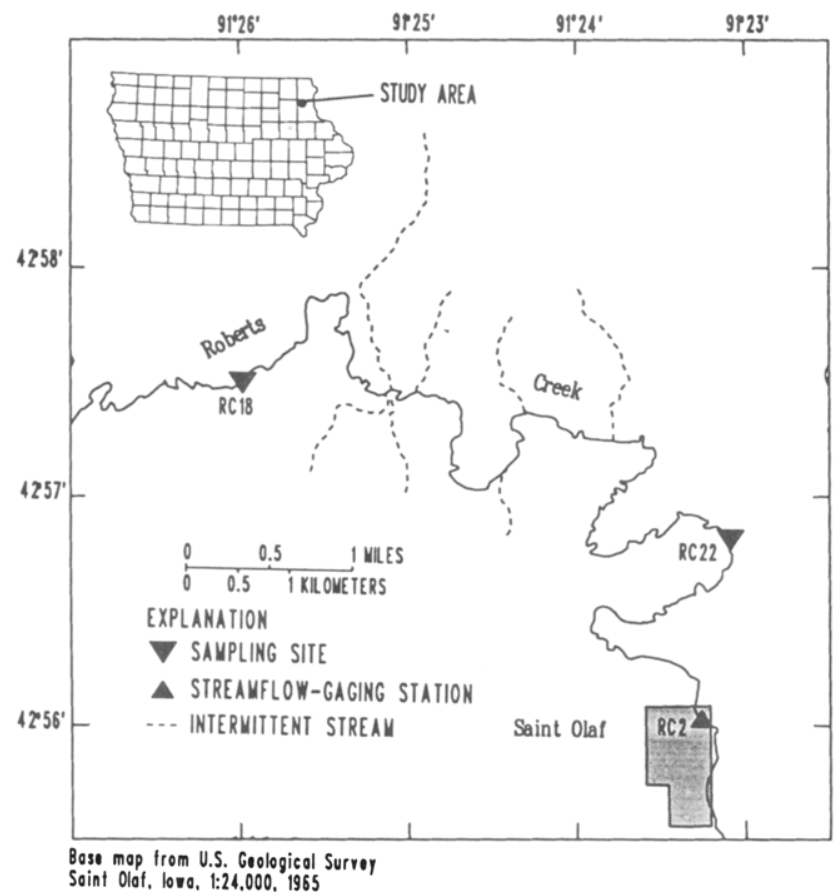

Soint Olaf, lowe, 1:24,000, 1965

Figure 1. Location of the study area and sampling sites.

in the computed travel times within the study reach.

Time of Travel. Predictive curves for the leading edge, peak concentration, and the trailing edge of a pulse of atrazine entering the study reach were obtained by conducting two dye tracer tests at low- and median-streamflow conditions. A more complete explanation of how these tests were performed and how the predictive curves can be used is presented by Kolpin and Kalkhoff (15). For this study, a peak concentration predictive travel time and discharge curve was used. Using the predictive travel time and discharge curve, approximately the same parcel of water can be tracked through the study reach.

Sampling Sites. Two sampling sites were emphasized for this study (Figure 1). Sampling site RC22 is $11.2 \mathrm{~km}$ downstream of site RC18. Water quality measurements at these sites represent the concentration of atrazine entering $(\mathrm{RC} 18)$ and exiting $(\mathrm{RC} 22)$ this system. Sampling occurred at various times from April 11 through December 2,1990 , at $\sim 1$-month intervals. Several conditions were required before samples were collected: (1) the streamflow was at or less than median flow; (2) there had been no significant rainfall for several days prior to the start of sampling; (3) streamflow was stable or slowly decreasing; (4) no major storm systems were in the 5-day extended forecast. Due to the extremely wet spring and early summer of 1990, it was difficult to find a sampling opportunity that met all of the criteria. Several sampling periods were started during stable flows only to have rain move into the area before the sampling period ended. Seven sampling periods that met the criteria were finally completed, and their relation to the discharge at site $\mathrm{RC} 2$ is shown in Figure 2. Discharge and water quality data were collected for three sites located between RC18 and RC22 and are published elsewhere (12).

Sampling. Each sampling period began with a stream discharge measurement at the upstream site (RC18). When the discharge was determined at this site, the predictive travel time and discharge relation was used to calculate the time required for a parcel of water to travel downstream to site $\mathrm{RC} 22$.

Samples were collected, and stream discharge was measured at the calculated time for each site. Samples

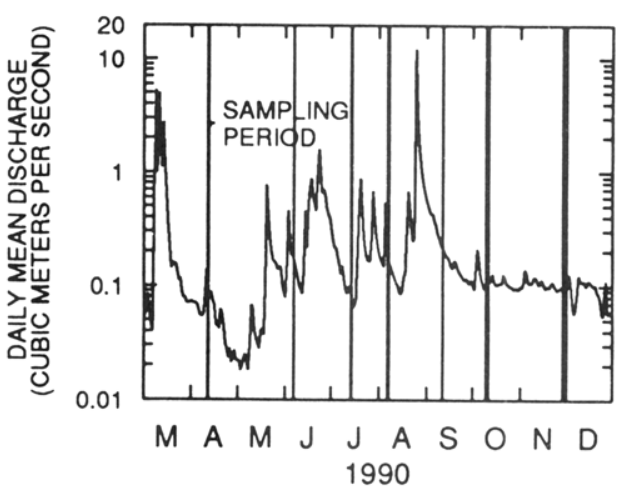

Flgure 2. Relation between sampling period and discharge at site RC2 (vertical shading represents duration of each sampling period).

for herbicide analysis were collected from a single point in the center of the stream using a dip method and stored in amber, baked-glass bottles. This single sample collected from the center of flow is an appropriate representation of the streamwater quality at the sampling site during base flow conditions. Differences in the concentrations of atrazine, desethylatrazine, and deisopropylatrazine were less than $5 \%$, well within analytical error, from replicate samples collected one-quarter of the stream-width distance from each bank. Once collected, each sample was filtered through a $1-\mu \mathrm{m}$ glass-fiber filter to remove particulate material detrimental to the solid-phase extraction method. Filtered samples were chilled immediately and stored in an ice chest for shipment to the laboratory. Unfiltered samples were collected and preserved with sulfuric acid for the analysis of nitrate. Suspended-sediment concentrations were determined from depth-integrated samples if the stream had sufficient depth or from a dip sample if the stream was too shallow. Stream discharge at each site was measured using standard current meter methods (17).

Laboratory Analysis. Herbicide samples were sent to the U.S. Geological Survey laboratory in Lawrence, KS, for the analysis of atrazine and two of its initial degradation products, desethylatrazine [2-amino-4-chloro-6-(isopropylamino)-s-triazine] and deisopropylatrazine [2amino-4-chloro-6-(ethylamino)-s-triazine]. These analytes were isolated by solid-phase extraction and analyzed by gas chromatography/mass spectrometry (GC/MS) (18). The GC/MS minimum reporting limit for the analytes is $0.05 \mu \mathrm{g} / \mathrm{L}$. Results of the analyses of eight duplicate samples showed that the variation in the analyses was $12 \%$ or less for atrazine, $15 \%$ or less for desethylatrazine, and $33 \%$ or less for deisopropylatrazine. The largest analytical variation was for samples that contained concentrations near the reporting limit. The mean of duplicate samples was used for interpretation. Samples also were analyzed for alachlor, ametryn, cyanazine, metolachlor, metribuzin, prometon, prometryn, propazine, simazine, and terbutryn at similar reporting limits. Results of these analyses are published elsewhere (12).

The analysis of samples for nitrate as nitrogen was done by the University of Iowa Hygienic Laboratory using U.S. Environmental Protection Agency method 353.2 (19). The minimum analytical reporting level for this method is 0.1 $\mathrm{mg} / \mathrm{L}$.

\section{Results}

Table I shows the changes in atrazine concentration as water entered and exited the study reach. Atrazine concentrations decreased substantially (about 25-60\%) for four sampling periods, decreased slightly (12\%) for one 
Table I. Travel Times and Results of Water Quality Analyses for Each Sampling Period

\begin{tabular}{|c|c|c|c|c|c|c|c|c|c|}
\hline \multirow[b]{2}{*}{$\begin{array}{c}\text { site } \\
\text { (Figure 1) }\end{array}$} & \multirow[b]{2}{*}{$\begin{array}{l}\text { sample } \\
\text { date }\end{array}$} & \multirow[b]{2}{*}{$\begin{array}{c}\text { time } \\
(24 \mathrm{~h})\end{array}$} & \multirow{2}{*}{$\begin{array}{l}\text { cumulative } \\
\text { travel time } \\
\text { (h) }\end{array}$} & \multirow{2}{*}{$\begin{array}{c}\text { stream } \\
\text { discharge } \\
\left(\mathrm{m}^{3} / \mathrm{s}\right)\end{array}$} & \multirow{2}{*}{$\begin{array}{c}\text { nitrite }+ \\
\text { nitrate } \\
(\mathrm{mg} / \mathrm{L})\end{array}$} & \multicolumn{3}{|c|}{$\operatorname{conen}(\mu \mathrm{g} / \mathrm{L})$} & \multirow{2}{*}{$\begin{array}{c}\text { atrazine } \\
\text { half-life } \\
\text { (h) }\end{array}$} \\
\hline & & & & & & atrazine & $\begin{array}{l}\text { desethyl- } \\
\text { atrazine }\end{array}$ & $\begin{array}{l}\text { deisopropyl- } \\
\text { atrazine }\end{array}$ & \\
\hline RC18 & $4-11-90$ & 1330 & 0 & 0.238 & 2.9 & 0.69 & 0.16 & 0.05 & \\
\hline $\mathrm{RC} 22$ & $4-13-90$ & 0730 & 42.0 & 0.089 & 2.5 & 0.48 & 0.18 & 0.07 & 80.2 \\
\hline $\mathrm{RC} 18$ & $6-06-90$ & 1200 & 0 & 0.244 & 7.2 & 4.85 & 0.67 & 0.34 & \\
\hline $\mathrm{RC} 22$ & $6-07-90$ & 2005 & 32.1 & 0.162 & 7.3 & 8.94 & 1.05 & 0.45 & $a$ \\
\hline $\mathrm{RCI8}$ & $7-13-90$ & 1845 & 0 & 0.204 & 3.8 & 0.37 & 0.21 & $<0.05$ & \\
\hline $\mathrm{RC} 22$ & $7-15-90$ & 1705 & 46.4 & 0.099 & 3.0 & 0.15 & 0.07 & $<0.05$ & 35.6 \\
\hline $\mathrm{RC} 18$ & $8-06-90$ & 1930 & 0 & 0.238 & 6.2 & 2.49 & 0.77 & 0.25 & \\
\hline $\mathrm{RC} 22$ & $8-08-90$ & 0515 & 33.8 & 0.177 & 5.2 & 1.83 & 0.69 & 0.19 & 76.1 \\
\hline $\mathrm{RC} 18$ & $9-11-90$ & 0900 & 0 & 0.264 & 6.7 & 0.24 & 0.21 & 0.08 & \\
\hline $\mathrm{RC} 22$ & $9-12-90$ & 1300 & 28.0 & 0.213 & 6.0 & 0.21 & 0.19 & 0.06 & 145 \\
\hline $\mathrm{RC} 18$ & $10-09-90$ & 1245 & 0 & 0.165 & 3.4 & 0.40 & 0.14 & 0.06 & \\
\hline $\mathrm{RC} 22$ & $10-12-90$ & 1040 & 69.9 & 0.109 & 2.4 & 0.30 & 0.17 & 0.06 & 168 \\
\hline RC18 & $11-28-90$ & 1230 & 0 & 0.147 & 3.5 & 0.09 & 0.10 & $<0.05$ & \\
\hline $\mathrm{RC} 22$ & $12-02-90$ & 0430 & 88.0 & 0.086 & 3.1 & 0.09 & 0.10 & $<0.05$ & $b$ \\
\hline
\end{tabular}

sampling period, increased (84\%) for one sampling period, and remained unchanged for one period as the parcel of water traveled from site RC18 to site RC22. Based on the analyses of duplicate samples, a concentration difference greater than $\sim 20 \%$ should constitute real differences not caused by laboratory variability.

Concentrations of the two atrazine degradation products analyzed remained essentially unchanged downstream during most sampling periods. The desethylatrazine concentration decreased substantially $(67 \%)$ downstream only during the July sampling period and varied little during most other sampling periods. However, concentrations of desethylatrazine increased $(57 \%)$ downstream during the June sampling period. The deisopropylatrazine concentration was near or less than the minimum analytical detection limit during five of the seven sampling periods and did not change substantially downstream during these times. Only the August sampling period had a substantial decrease $(24 \%)$ in deisopropylatrazine concentration downstream through the study reach. The June sampling period had a $32 \%$ increase in concentration.

Atrazine, desethylatrazine, and deisopropylatrazine concentrations increased from site RC18 to site RC22 during the June sampling period (Table I). This contrasts with other sampling periods during the study. The June sampling period is unique in that the sample collection occurred soon after a storm (Figure 2) following the application of herbicides. The runoff generated from this storm flushed large concentrations of atrazine and atrazine metabolites into the stream. The increased stream levels associated with this storm generated bank storage of water containing these large concentrations. Although there was a net loss of streamflow in the study reach from seepage into the stream bed (Table I) during the June sampling period, there was some input from a release of water from bank storage. This release from bank storage was the most likely origin of the apparent input of atrazine and atrazine metabolites in the study reach during this time.

\section{Discussion}

Atrazine is not conserved in the study reach of Roberts Creek. Atrazine concentrations in water entering the study reach (RC18) are generally greater than concentrations in the same parcel of water as it exits the study reach (RC22) during stable flow conditions. There are four possible explanations for the decrease in atrazine concentration: (1) removal by sorption to sediment, (2) dilution, (3) volatilization, and (4) degradation. The process of sorption does not appear sufficient to explain the observed amount of atrazine loss. Researchers have documented that only trace amounts of atrazine are associated with suspended sediment $(2,20)$. About $99 \%$ of the compound is reported to reside in the dissolved phase. The exact amount of atrazine sorped to suspended sediment in this study could not be determined because the filtering process removed some suspended sediment from the samples. Dilution is not a plausible explanation for the decrease in atrazine concentration because, except for the June sampling period, there was no surface water or groundwater contribution to the study reach during the sampling periods. A consistent decrease in discharge between the sampling sites and the water-level gradient between the stream and the fractured bedrock aquifer underlying the stream (16) indicates that there is only a small likelihood of groundwater contributions to streamflow. Although volatilization is an important process in loss of atrazine from soils (21-23), little work has been done investigating its importance in surface water. Research on other organic compounds (24) suggests that some volatilization of atrazine across the air/water interface may take place, but it is thought to be a minor process in this environment. The remaining process that could account for the amount of decrease in atrazine concentration is degradation.

The documentation of atrazine degradation in surface water under field conditions is a significant finding. Because a majority of midwestern streams have been found to contain atrazine (3), the atrazine degradation reported in Roberts Creek is likely occurring in many small streams in this region. Many of these small streams also have physical characteristics, land use patterns in the watershed, and aquatic and riparian vegetation similar to that of Roberts Creek. The amount of atrazine degradation that may be occurring in these streams may be difficult to measure because, unlike this section of Roberts Creek, most have groundwater or surface water sources contributing to streamflow. Although this reported atrazine degradation may not be extrapolated to large rivers without further investigation, it is streams the size of Roberts Creek which drain directly into these larger rivers or their tributaries. Thus, the amount of atrazine in these larger rivers is indirectly affected by the degradation of atrazine that appears to be occurring in small streams.

Atrazine Degradation. Atrazine can be degraded by either biotic or abiotic processes (25-27). The biotic degradation of atrazine generally results in $\mathrm{N}$-dealkylation of the atrazine structure to initially produce either desethylatrazine or deisopropylatrazine (26). Research has shown desethylatrazine to be the more stable and domi- 
nant initial biotic degradation product $(8,28)$. Laboratory experiments using bacteria and microbes have shown atrazine to be recalcitrant to microbial degradation in aqueous solutions $(28,29)$. Laboratory research also has shown that there is limited uptake and metabolism of atrazine by algae (30-32). The abiotic degradation of atrazine results in the hydrolysis of the atrazine structure to form an initial degradation product of hydroxyatrazine [2-hydroxy-4-(ethylamino)-6-(isopropylamino)-s-triazine] (33). Laboratory research has documented rapid degradation of atrazine in aqueous solutions and surface water samples by photolysis $(13,34,35)$. This laboratory research suggests that indirect photolysis of atrazine may be a more important mechanism than direct photolysis in the degradation process (13). Research has also shown atrazine to degrade by particle-catalyzed hydrolysis $(14,36)$, although this process may be more important in soil compared to aqueous environments due to the substantially greater soil to water ratio.

Results of the Roberts Creek study indicate that substantial instream degradation of atrazine occurred during four of the sampling periods. An examination of the atrazine metabolite concentrations available may provide clues to the type of degradation process taking place. The transformation rates of the two initial biotic degradation products of atrazine are not clearly defined. If these transformation rates are relatively slow and biotic degradation of atrazine is taking place, the concentrations of desethylatrazine and deisopropylatrazine should be inversely related to the concentration of atrazine. Decreasing atrazine concentrations downstream would be accompanied by increasing biotic degradation product concentrations. During this study, when atrazine concentrations decreased, the concentrations of the initial biotic degradation products of atrazine either remained unchanged or, at times, were decreasing. Because the concentrations of desethylatrazine and deisopropylatrazine do not have an inverse relation to atrazine, either (1) abiotic activity is the primary atrazine degradation process in the stream environment, which seems to agree with previously described laboratory work, (2) there is rapid transformation of desethylatrazine and deisopropylatrazine to the next degradation product in the degradation chain, or (3) the numerous aquatic plants present are removing atrazine from the system through internal degradation or temporary storage within the plant structure. Without data confirming an inverse relation between atrazine and hydroxyatrazine concentrations, for which the analysis was not available, the occurrence of abiotic degradation of atrazine can only be inferred.

Atrazine Half-Life. The degradation rate of atrazine, as determined from the atrazine half-life, varied throughout the study (Table I). To determine atrazine half-life, an assumption of no input of new atrazine within the study reach was made. The geohydrologic conditions of the study reach, absence of surface water and groundwater contributions to streamflow, generally make this assumption valid. Atrazine half-life was calculated, assuming pseudo-first-order kinetics, by first determining the reaction constant $(k)$, using the following equation:

$$
k=-\ln \left(A / A_{0}\right) t
$$

where $A$ is the atrazine concentration at the downstream site (in $\mu \mathrm{g} / \mathrm{L}$ ), $A_{0}$ is the atrazine concentration at the upstream site (in $\mu \mathrm{g} / \mathrm{L}$ ), and $t$ is the travel time from upstream to downstream site (in $h$ ). The reaction constant (k) then was used to determine atrazine half-life $\left(T_{1 / 2}\right)$ :

$$
T_{1 / 2}=\ln 2 / k
$$

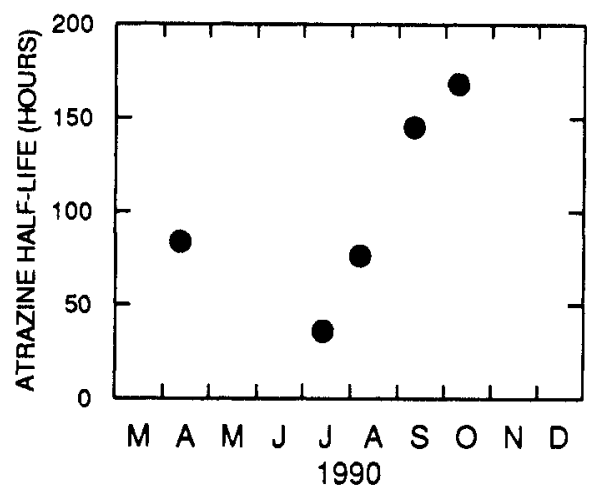

Figure 3. Relation of atrazine half-life to date of sample collection.

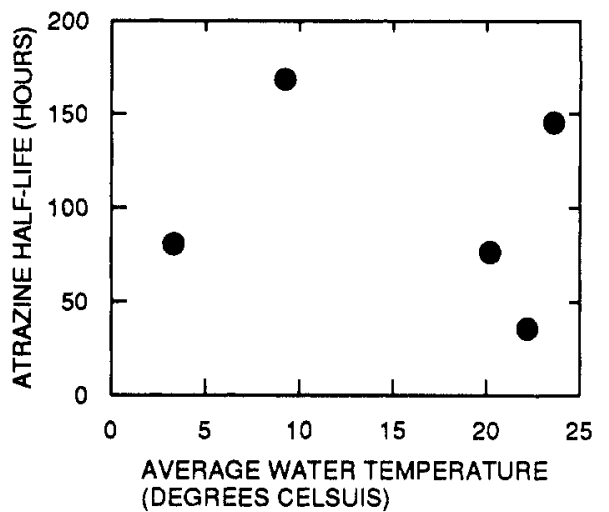

Flgure 4. Relatlon of atrazine half-llfe to average water temperature in the study reach.

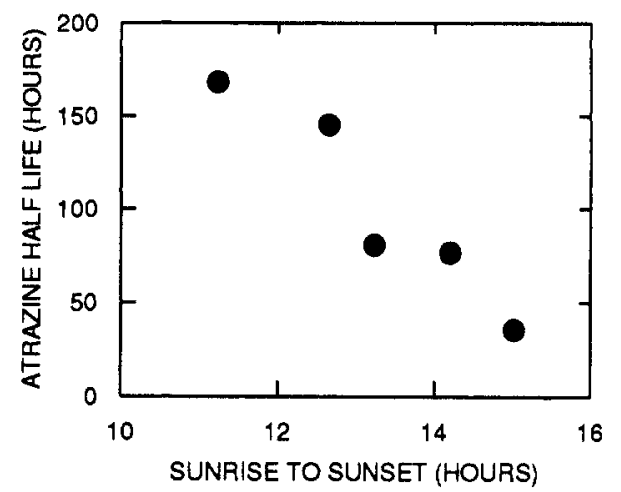

Flgure 5. Relation of atrazine half-life to daily hours of sunlight.

A seasonal pattern in atrazine half-life is shown in Figure 3 , with the maximum degradation rate (minimum half-life) occurring during the July sampling period. This seasonal trend in atrazine degradation rate provides no indication as to whether it is biotic or abiotic degradation that is occurring. Both processes most likely would exhibit similar trends through a single season, with the seasonal increase and subsequent decrease of water temperature and photosynthesis affecting the rate of biotic atrazine degradation and the seasonal increase and subsequent decrease of daylight hours affecting the rate of photolytic atrazine degradation.

There were no direct measurements of either biotic activity or photolytic activity for this study, although water temperature and day length may be used as a indirect measurement of biotic and abiotic degradation rates. There was no significant $(p>0.05)$ relation between atrazine half-life and the water temperature (Figure 4). Atrazine half-life had a significant $(p<0.05)$ inverse relation with daily hours of sunlight during each sampling 


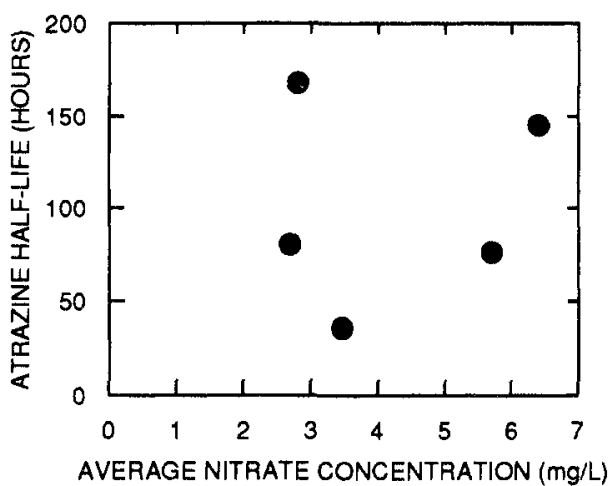

Flgure 6. Relation of atrazine half-life to average nitrate concentration in the study reach.

period (Figure 5). The shortest half-life occurred during the July sampling period, when there was $\sim 15 \mathrm{~h}$ of sunlight, and the longest half-life occurred during the November sampling period, when there was $\sim 9 \mathrm{~h}$ of sunlight. These results support the inference that the amount of sunlight is an important factor in atrazine degradation in streams and that photolytic degradation may be occurring.

Laboratory experiments by Goldberg et al. (13) concluded that atrazine degraded by indirect photolysis and that the rate of photolytic atrazine degradation increased (half-life decreased) with increasing nitrate concentrations in the water. The nitrate ions acts as a catalyst by producing hydroxyl radicals in water in the presence of sunlight. These hydroxyl radicals then attack the atrazine structure to form hydroxyatrazine, which initiates the abiotic degradation chain for atrazine. During this study, there was no statistically significant $(p>0.05)$ relation between the atrazine half-life and the average nitrate concentration in the study reach (Figure 6). This absence of a significant relation between nitrate and atrazine half-life does not contradict Goldberg's findings. The strong seasonal pattern in atrazine half-life likely masks any potential relation between nitrate concentration in the water and the rate of atrazine degradation.

\section{Conclusions}

Atrazine was not conserved in Roberts Creek, a small stream in northeastern Iowa, during stable low- to medium-flow conditions. It is felt that the decrease in atrazine concentration between water entering the system and that leaving the system was due to instream degradation processes. Concentrations of desethylatrazine and deisopropylatrazine, two initial biotic degradation products, were generally constant or decreased between water entering and leaving the system. The lack of an inverse relation between the concentrations of atrazine and the biotic degradation products analyzed suggests that abiotic degradation processes may be occurring in the stream. The atrazine degradation rate, as indicated by atrazine half-life, was significantly correlated with daily hours of sunlight, an indirect measurement of photolytic activity. Additional research is needed to examine hydroxyatrazine, along with atrazine and its two initial biotic degradation products, in both water and suspended sediment to verify the occurrence of photolytic degradation of atrazine in small streams.

The results of this study are important because it documents the degradation of atrazine in surface water under field conditions. This finding has transfer value beyond the karstic region of northeast Iowa. It has been determined that many midwestern streams contain atrazine (3). Many of these streams, comparable in size to Roberts
Creek, have similar physical characteristics, land-use patterns in the watershed, and stream and riparian vegetation. Thus, documenting the existence of atrazine degradation in the study reach of Roberts Creek suggests that atrazine degradation may be occurring, in varying degrees, in other midwestern streams.

\section{Literature Cited}

(1) Hartzler, R.; Wintersteen, W. K. A Survey of Pesticides Used in Iowa Crop Production in 1990; Iowa State University Extension Pamphlet Pm-1288; Iowa State University: Ames, IA, 1991.

(2) Squillace, P. J.; Thurman, E. M. Environ. Sci. Technol. $1992,26,538-545$.

(3) Thurman, E. M.; Goolsby, D. A.; Meyer, M. T.; Kolpin, D. W. Environ. Sci. Technol. 1991, 25, 1794-1796.

(4) Kalkhoff, S. J.; Kuzniar, R. J. Hydrologic data for the Big Spring Basin, Clayton County, Iowa, Water Year 1989. U.S. Geol. Surv. Open-File Rep. 1991, No. 91-63.

(5) Harris, C. I. J. Agric. Food Chem. 1967, 15, 157-162.

(6) Skipper, H. D.; Gilmour, C. M.; Furtrick, W. R. Soil Sci. Soc. Am. Proc. 1967, 31, 653-656.

(7) Muir, D. C. G.; Baker, B. E. Weed Res. 1978, 18, 111-120.

(8) Adams, C. D.; Thurman, E. M. J. Environ. Qual. 1991, 20, 540-547.

(9) Agertved, J.; Rugge, K.; Barker, J. F. Ground Water 1992 , $30,500-506$

(10) Roberts, G. C.; Sirons, C. J.; Frank, R.; Collins, H. E. J Great Lakes Res. 1979, 5, 246-255.

(11) Kalkhoff, S. J. Hydrologic Data for the Big Spring Basin, Clayton County, Iowa, Water Year 1988. U.S. Geol. Surv. Open-File Rep. 1989, No. 89-230.

(12) Kalkhoff, S. J.; Kuzniar, R. J.; Kolpin, D. W.; Harvey, C. A. Hydrologic Data for the Big Spring Basin, Clayton County, Iowa, Water Year 1990. U.S. Geol. Survey, Open-File Rep. 1992, No. 92-67.

(13) Goldberg, M. C.; Cunningham, K. M.; Squillace, P. J. Photolytic Degradation of Atrazine in the Cedar River, Iowa, and Its Tributaries. In U.S. Geological Survey Toxic Substances Hydrology Program-Proceedings of the Technical Meeting; Mallard, G. E., Aronson, D. A., Eds.; Monterey, CA, March 11-15, 1991; U.S. Geol. Survey, Water-Resour. Invest. Rep. 1991, No. 91-4034.

(14) Jones, T. W.; Kemp, W. M.; Stevenson, J. C.; Means, J. C. J. Environ. Qual. 1982, 11, 632-638.

(15) Kolpin, D. W.; Kalkhoff, S. J. Time of Travel and Dispersion in a Selected Reach of Roberts Creek, Clayton County, Iowa. U.S. Geol. Survey, Water-Resour. Invest. Rep. 1991, No. 91-4145.

(16) Hallberg, G. R.; Hoyer, B. E.; Bettis, E. A.; Libra, R. D. Hydrogeology, Water Quality, and Land Management in the Big Spring Basin, Clayton County, Iowa. Iowa Geol. Surv. Bureau Open-File Rep. 1983, No. 83-3.

(17) Buchanan, T. J.; Somers, W. P. Discharge Measurements at Gaging Stations. U.S. Geol. Surv. Tech. Water-Resour. Invest. 1969; Book 3, Chapter A8.

(18) Thurman, E. M.; Meyer, M. T.; Pomes, M. L.; Perry, C. A Schwab, A. P. Anal. Chem. 1990, 62, 2043-2048.

(19) Methods for Chemical Analyses of Water and Wastes; EPA-600/4-79-020; U.S. Environmental Protection Agency, 1983.

(20) Pereira, W. E.; Rostad, C. E. Environ. Sci. Technol. 1990 $24,1400-1406$

(21) Buser, H. R. Environ. Sci. Technol. 1990, 24, 1049-1058.

(22) Glotfelty, D. E.; Leech, M. M.; Jersey, J.; Taylor, A. W. J. Agric. Food Chem. 1989, 37, 546-551.

(23) Plimmer, J. R. Am. J. Ind. Med. 1990, 18, 461-466.

(24) Baker, J. E.; Eisenreich, S. J. Environ. Sci. Technol. 1990, $24,342-352$

(25) Goswami, K. H.; Green, R. E. Environ. Sci. Technol. 1971, $5,426-429$

(26) Paris, D. F.; Lewis, D. L. Resid. Rev. 1973, 45, 95-124.

(27) Wehtje, G. R.; Spalding, R. F.; Burnside, O. C.; Lowry, S. R.; Leavitt, J. R. C. Weed Sci. 1983, 31, 610-618.

(28) Geller, A. Arch. Environ. Contam. Toxicol. 1980, 9, 289-305. 
(29) Dries, D.; De Corte, B.; Liessens, J.; Steurbaut, W.; Dejonckheere, W.; Verstraete, W. Biotechnol. Lett. 1987, 9, 811-816.

(30) Jones, T. W.; Winchell, L. J. Environ. Qual. 1984, 13, 243-247.

(31) Valentine, J. P.; Bingham, S. W. Can. J. Bot. 1976, 54, 2100-2107.

(32) Butler, G. L.; Deason, T. R.; O'Kelley, J. C. Bull. Environ. Contam. Toxicol. 1975, 13, 149-152.

(33) Pape, B. E.; Zabik, M. J. J. Agri. Food Chem. 1970, 18, 202-207.

(34) Pelizzetti, E.; Tosato, M. L. Environ. Sci. Technol. 1990, 24, 1559-1565.

(35) Frimmel, F. H.; Hessler, D. P. Photochemical Degradation of Triazine and Anilide Pesticides in Natural Waters. Abstracts of Papers, 203rd National Meeting of the Am- erican Chemical Society, San Francisco, CA, April 5-10, 1992; American Chemical Society: Washington, DC, 1992; AGRO 87.

(36) Armstrong, D.E.; Chesters, G. Environ. Sci. Technol. 1968, $2,683-689$

Received for review June 4, 1992. Revised manuscript received September 24, 1992. Accepted September 28, 1992. This study was supported, in part, by the Iowa Department of Natural Resources Geological Survey Bureau, through the Big Spring Basin Demonstration Project, with funds provided from the Iowa Groundwater Protection Act. Roger Koster, the Big Spring Project Coordinator for the Iowa State University Cooperative Extension Service, provided assistance in obtaining landowner cooperation in the study. 